\title{
The Best Times to Treat of Diseases
}

\author{
Eda Alemdar* \\ Department for Medicine, Dr. Goce Delcev University Medicine Faculty, Macedonia
}

Received: 州 September 4, 2018; Published: 邦 September 10, 2018

*Corresponding author: Eda Alemdar, Department for Medicine, Dr. Goce Delcev University Medicine Faculty, Macedonia

\begin{abstract}
Background: Many diseases occur at certain times and after specific process. Their treatment also needs to be done at a certain time. There are seasonal time and environments that make up the diseases. In parallel with the type of the disease, their treatment also requires a specific process and period. Treatments not made at the right time and in the right place do not yield results.
\end{abstract}

Aim of the study: The aim of this study is to show that treatment of diseases is related to the biological clock and the circadian rhythm.

Methods: In our study, classical medical data and modern medical studies were evaluated together. Eclectic method is used in the article. In our study, there are no astrological data.

Results: There are many factors that affect human health, from his/her own environment to the outside atmosphere such as sun and moon.

Conclusion: In the direction of this study, it is found out that there are certain times of day and night for the treatment of diseases.

\section{Introduction}

All physical nascence and developments, such as the human life, changes and development of plants, the life process of animals, sleep, and migration of some are directed, formed, and realized with a biological clock that acts in relation to various structures in organisms. The biological clock found in organisms is a biological rhythm that reflects the oscillations of night and day. This forms the psychological and physical and provides both stable regulation and oscillations that occur in living beings. It also shapes the way the body functions. A failure of this biological clock amidst this cycle within the operational shape of this rhythm is accepted as a basic factor of many diseases [1]. As a matter of fact, according to the Nobel prize-winning Sancar, most living organisms-animals, plants, fungi, and even some types of bacteria - have an internal clock, a circadian clock that orchestrates the biochemical, physiological and behavioral functions in each cell according to a 24-hour day-night cycle. This clock regulates sleeping and waking, hormone levels, body temperature, heart rate and blood pressure, among hundreds of other factors [2].

\section{Effect of external factors on diseases and treatments}

As stated in Liu's article [3], the seasons are an external factor and influence the physiological and mental dimensions of humans. This context contributes a significantly greater impression on those with health problems, just as it can affect healthy individuals. Brown
[4] expressed this as "human and animal physiology is subject to seasonal, moon, and circadian rhythms". According to some studies like Takemura and colleagues [5], general biologic rhythms linked to the lunar cycle can be classified based on circular lunar rhythms related to period characteristics that reflect the emergence of specific events/situations once or twice at the start of the month, respectively. A study by Reinberg looking at the relationship between biological rhythm and the moon, assumed that biological rhythms are an advantageous genetic adaptation and has a life value that results from the evolution of life forms in a changing environment thru the predictable cycles of 24 hours, month, and year. Of these periods, the 24-hour cycle of light/dark is the principle synchronizer. Indeed, the findings from Reinberg suggests that the reproduction over the same biological cycle observed in some plants and water-borne animals can be maintained between various species, including Homo sapiens [6].

Some researches finding regarding seasonal change and phenomena and the lunar cycle reveal a relationship and effects in relation to the moon and the living creatures on Earth. As a matter of fact, the lunar cycle is one of the basic factors of variable human psychology, according to the results of the study by Chakraborty and Della [7]. The relationship between the moon and living beings was a focus of interest for classical period Islamic physicians like Avicenna (d. 428/1037), Alberuni (d. 453/1061), they 
considered such a connection in their treatments [8]. For example, Akshamsaddin (d. 863/1459) recommended to patients that they take medicines each morning on an empty stomach during the fifteen days before the day of each new moon, which is the first half of the month [9]. At the same time, Alberuni and Alkindi (d. $252 / 866$ ) said that surgery must be performed based on the lunar cycle [10]. According to Erzurumlu (d. 1194/1780), the brain tissues of living creatures increases in the first half of the month and decreases in the second half. According to him, insects emerge and disperse in the first half of the month. Predatory animals are also very ambitious in pursuing prey during this time. The opposite is true in the second half of the month. Again, according to Erzurumlu, trees planted in the first half of the month grow and develop more quickly. Trees planted in the second half of the month are weak or dry. All fruits, flowers, and herbs grow and develop and become colorful in the first half of the month [11].

We encounter similar statements with Avicenna [12]. For example, physician Nasrullah said that studies for treatment conducted in the final third of the night is the most suitable time to obtain efficient results and engaged in this approach in line with the biological clock data indicating that this is the most suitable time for bodily hormone functioning. Again, according to Nasrullah, daily treatment in line with the lunar cycle must be in the early morning hours, during morning, which is the time zone that lasts from dawn until the sun rises. He again stated that more effective results can be obtained from food and medicine that are taken during the time between dawn and the rising of the sun [13]. According to classical period Islamic physicians, humans are exposed to positive or negative contributions from the place based and time on which time zone they are in. Classical period Islamic scholars who accept this directional influence emphasized that week, day, and hour can result in a positive contribution for people, especially in terms of health [14].

\section{Discussion}

In classical period Islamic medical studies, Like Ibn Sina, Akshamseddin and Erzurumlu [15], it is accepted that a specific time interval of the day forms with the effect of the environment and moon on the Earth. Moreover, there are times that are suitable in the functioning of the physiological structure of humans. This is called the natural rhythm of the biological clock when discussed in terms of modern medical data. At the same time Al-Biruni and AlKindi said that surgery must be performed based on the lunar cycle [16]. According to Erzurumlu (d. 1194/1780), the brain tissues of living creatures increases in the first half of the month and decreases in the second half. According to him, insects emerge and disperse in the first half of the month. Predatory animals are also very ambitious in pursuing prey during this time. The opposite is true in the second half of the month. Again, according to Erzurumlu, trees planted in the first half of the month grow and develop more quickly. Trees planted in the second half of the month are weak or dry.

All fruits, flowers and herbs grow and develop and become colorful in the first half of the month [17]. We encounter similar statements in Ibn Sina. According to Sancar who studies circadian clock and treatment timing, knowing how and when normal cells in various organs undergo DNA repair would help doctors understand the best times to administer drugs. For instance, cisplatin interferes with gene transcription to prevent cell division and growth. Ideally, it leads to cancer cell death [18]. According to researchers like Kwon and Song, the biological clock contains 24-hour night and day intervals. Similar results were proposed in the classical period. For example, physician Nasrullah said that studies for treatment conducted in the final third of the night is the most suitable time to obtain efficient results and engaged in this approach in line with the biological clock data indicating that this is the most suitable time for bodily hormone functioning [19].

Again, according to Nasrullah, daily treatment in line with the lunar cycle must be in the early morning hours, during morning, which is the time zone that lasts from dawn until the sun rises. He again stated that more effective results can be obtained from food and medicine that are taken during the time between dawn and the rising of the sun [20]. In this respect to this, Sancar, who works on the relationship between time and the treatment of diseases, says: "We found there are close to 2,000 genes, different parts of which are repaired at different times of day, depending on the gene. We believe understanding these circadian patterns and kinetics throughout the genome and in various organs will help us discover and develop better treatment regimens for people with cancer" [21-23]. The words, "different times of day" in this interview, is remarkable for our thesis.

\section{Conclusion}

Based on our study, the most convenient time zones for the treatment of diseases are the last one-third of the day and night times. Accordingly, the most convenient times for the treatments are the time zones which are before sunrise close to sunset. It should not be forgotten that this situation may change according to summer and winter and to the countries in the direction of latitude and longitude. The theses in our study offers theoretical information for future research. We believe that the data here will be a key resource for subsequent experiment-based studies.

\section{References}

1. Paganelli R, Petrarca C, Di Gioacchino M (2018) Biological clocks: their relevance to immune-allergic diseases. Clinical and Molecular Allergy 16(1): 2-8.

2. Kang TH, Boltz LAL, Reardon, JT, Aziz Sancar (2010) Circadian control of XPA and excision repair of cisplatin-DNA damage by cryptochrome and HERC2 ubiquitin ligase. PNAS 107(11): 4890-4985.

3. Liu F, Chang HC (2017) Physiological links of circadian clock and biological clock of aging. Protein Cell 8(7): 477-488.

4. Brown FAJ (1965) Propensity for lunar periodicity in hamsters and its significance for biological clock theories. Proc Soc Exp Biol Med 120(3): 792-797.

5. Takemura A, Rahman MS (2010) External and internal controls of lunarrelated reproductive rhythms in fishes. Journal of Fish Biology 76(1): 7-26.

6. Reinberg A, Smolensky MM, Touitou Y (2016) The full moon as a synchronizer of circa-monthly biological rhythms: Chronobiologic 
perspectives based on multidisciplinary naturalistic research. Journal Chronobiology International: The Journal of Biological and Medical Rhythm Research 33(5): 465-479.

7. Chakraborty U (2014) Effects of different phases of the lunar month on humans. Biological Rhythm Research 45(3): 383-396.

8. Della M, Atzori G, Dijk DJ (2015) Effects of lunar phase on sleep in men and women in Surrey. Journal of Sleep Research 24(6): 687-694.

9. Ibn Sina EAS (2017) The Canon of Medicine Al-Kanun fi al-tıbb [in Arabic] trs. to Turkish by Esin Kahya. Ankara: Ataturk Culture Center Publications 4: 208-211.

10. Akhshamsaddin MH Material of life Madda al-Hayat [in Ottoman Turkish codex] Library of Suleymaniye. Vehbi Efendi, Istanbul, Turkey, 1462(1271): 12 .

11. Turner HR (2006) Science in Medieval Islam: An Illustrated Introduction. University of Texas Press, Texsas, USA, p. 114.

12. Erzurumlu IH (1981) Islamic Cosmology and Astronomy (Marifetnama [in Turkish]). Veli Publications, Istanbul, Turkey, 147-148.

13. Ibn Sina EAS (2017) The Canon of Medicine (Al-Kanun fi al-tıbb [in Arabic] trs. to Turkish by Esin Kahya. Ataturk Culture Center Publications, Ankara, Turkey, 4: 208-211.

14. Nasrullah SS Best description of protecting the human body (Gayat albeyan fi tadbir beden al-insan [in Arabic]) Library of Kayseri Rashid Efendi, Turkey, 1243(1109): 13-14.

\section{ISSN: 2574-1241}

DOI: $10.26717 / B J S T R .2018 .08 .001720$

Eda Alemdar. Biomed J Sci \& Tech Res

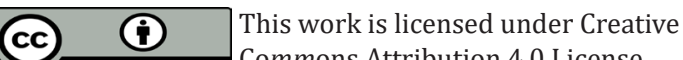

Submission Link: https://biomedres.us/submit-manuscript.php
15. Alemdar E (2018) External Factors that Direct the Biological Clock and Role in Treatment of Disease. Arch Med 3(3): 1-7.

16. Ibn Sina EAS (2017) The Canon of Medicine Al-Kanun fi al-tıbb [in Arabic] trs. to Turkish by Esin Kahya. Ataturk Culture Center Publications, Ankara, Turkey, 4: 208-211.

17. Turner HR (2006) Science in Medieval Islam: An Illustrated Introduction. University of Texas Press, Texsas, Turkey, p. 114.

18. Erzurumlu IH (1981) Islamic Cosmology and Astronomy (Marifetnama [in Turkish]). Veli Publications, Istanbul, p. 147-148.

19. Yang Y, Adebali O, Wu G, Selby CP, Chiou YY, et al., (2018) CisplatinDNA adduct repair of transcribed genes is controlled by two circadian programs in mouse tissues. PNAS 115(21): 4777-4785.

20. Kwon O, Yu JH, Jeong E, Yoo HJ, Kim MS (2018) Meal-related oscillations in the serum serotonin levels in healthy young men. Clin Endocrinol 88(4): 549-555.

21. Song Y, Choi G, Jang L, Park H, Kim SW, et al. (2018) Circadian rhythm gene expression and daily melatonin levels vary in athletes and sedentary males. Biol Rhythm Res 49: 237-245.

22. Nasrullah SS Best description of protecting the human body (Gayat albeyan fi tadbir beden al-insan [in Arabic]) Library of Kayseri Rashid Efendi, Turkey, 1243(1109): 13-14.

23. Sancar A (2018) Could reading our circadian clocks according to DNA repair optimize chemotherapy? UNC Health Care. 2018.

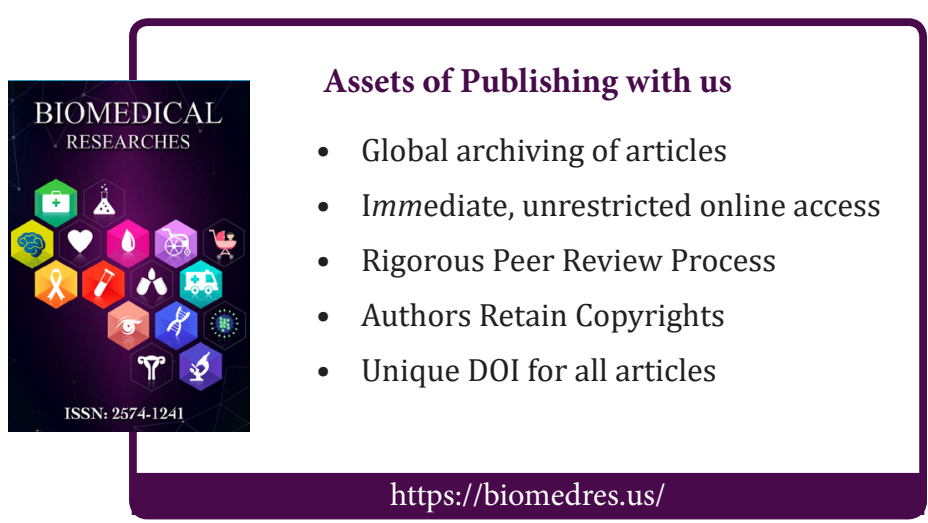

